\title{
Food and social identity: Rural lives that appear through food
}

\author{
Alimentação e identidade social: vidas rurais \\ que aparecem pela comida
}

Eliziane Nicolodi Francescato RUIZ1 (iD) 0000-0002-8632-6612

Tatiana Engel GERHARDT² (D) 0000-0001-8707-6347

A B S T R A C T

\section{Objective}

The objective was to analyze the interactions between food and identity by exploring the daily food eaten by a rural community. Under the gift theory view, the aim is to present readings concerning a rural identity that the research participants constituted through eating; this aim is premised on the assumption that analyzing the relationship between the identity of a group and eating becomes important because of the marked influence that belonging to a collective has in food.

\section{Methods}

An ethnographic approach was used including participant observation, field diary annotations, and interviews with 21 interlocutors.

\section{Results}

The activity of eating produced at least two categories that characterized rural identity: one marked by the stigma of the past, and the other by values that, above all, denote a reaction to stigma; a reaction to stigma is linked to the work that also sustains the honor of a family, the consumption of food/goods common in the city, inclusion in a larger society, and commitment to the collective.

\section{Conclusion}

Eating, in addition to the biological and individual, can also be apprehended as a complex and revealing sociocultural phenomenon, including ways of belonging to a group. With food a marked rural identity appears, mainly through reactions to stigmata.

Keywords: Ethnography. Food. Rural population.

\footnotetext{
1 Universidade Federal do Rio Grande do Sul, Departamento de Nutrição, Programa de Pós-Graduação em Desenvolvimento Rural. Av. João Pessoa, 31, 90040-000, Porto Alegre, RS, Brasil. Correspondence to: ENF RUIZ. E-mail: <elizianeruiz@yahoo.com.br>.

2 Universidade Federal do Rio Grande do Sul, Escola de Enfermagem, Programa de Pós-Graduação em Desenvolvimento Rural. Porto Alegre, RS, Brasil.

Article based on the thesis of ENF RUIZ, entitled "Relações sociais nas situações de adoecimento crônico no rural: expressões de cuidado e de sofrimento na perspectiva da dádiva". Universidade Federal do Rio Grande do Sul; 2013.
}

How to cite this article

Ruiz ENF, Gerhardt TE. Food and social identity: Rural lives that appear through food. Rev Nutr. 2019;32:e180058. http:// dx.doi.org/10.1590/1678-9865201932e180058 


\section{R E S U M O}

\section{Objetivo}

Analisar as interações entre a comida e a identidade explorando o comer cotidiano de uma comunidade rural. Procurou-se, a partir do referencial teórico da Dádiva, expor leituras de uma identidade rural que os interlocutores da pesquisa fizeram aparecer a partir do comer, partindo do princípio de que analisar a relação entre a identidade de um grupo e o comer se torna importante pela influência marcante que o pertencimento a um coletivo possui na alimentação.

\section{Métodos}

Empregou-se a abordagem etnográfica com uso de observação participante, anotações em diário de campo e entrevistas com 21 interlocutores.

\section{Resultados}

O comer fez aparecer pelo menos duas categorias que caracterizam a identidade rural: uma marcada por estigmas do passado e, outra, por valores que, acima de tudo, denotam reação ao estigma e que estão ligados ao valor do trabalho que sustenta também a honra da família, ao consumo de alimentos/bens comuns na cidade e que falam da inclusão em uma sociedade maior, bem como ao compromisso com o coletivo.

\section{Conclusão}

A alimentação, para além do biológico e do individual, também pode ser apreendida com fenômeno sociocultural complexo e revelador, inclusive, de modos de pertencer a um grupo. Com a comida apareceu uma identidade rural marcada, sobretudo, por reações a estigmas.

Palavras-chave: Etnografia. Alimentação. População rural.

\section{NTRODUCTION}

With diet, as with other aspects inherent to human existence, there is a meeting of nature (the biological), culture, and the contexts of life [1]. People find ways to realize the need to feed themselves from a specific way of seeing the world and their place in it. In other words, for humans, food is transformative: the vital necessity for food is not just a sensory level appreciation, it also has a sociocultural context $[2,3]$.

Matta [4], in pointing to the sociocultural meaning of diet, states that every nutritive substance can be a source of nourishment, but not every source is food. Nourishment refers to a need that is in every human being, but food, eating, and the rules that govern them are something that transforms the impersonal into a personal and group characteristic [3,5-7].

Eating marks our existence and our belonging to a community and it is something that takes place every day of our lives; therefore, it constitutes an important window into the study of societies [8]. To analyze eating is also to weave readings of social relations and identities that are attributed and claimed, through which humanity orients and distinguishes itself [9-13].

Therefore, this article aims to analyze the interactions between food and identity by exploring the daily eating habits of a rural community. This is particularly important in the debate on the value of rural life, in which food, owing to its specific nature, is practically invisible within the fields of knowledge and practice that examine the rural as an object of study and intervention $[14,15]$.

Marcel Mauss's theory expressed in "The Gift" [16] is an important resource for grasping group identity through food. In Mauss's theory, the gift consists of a set of benefits and considerations that occur through a cycle marked by the obligation (and freedom) to give, receive, and reciprocate material or immaterial goods that have relevance in the production of societies $[17,18]$. Analyzing the 
phenomena that have occurred in the most diverse societies described by anthropologists, among them Malinowski, Mauss [16] found that the exchange of goods (objects, food, gifts, feasts) that governed relations between groups and individuals represented more than the acts necessary to maintain economic and physical reproduction. There were other motivations that concerned social reproduction, because with the exchange of goods came the honor, the hierarchy, the power, and the norms that signaled the mode of group living.

The important contribution of gift theory to the understanding of society lies in the perspective that, above material things, what circulates between people and what links them, are symbols - the spirit of the thing [19]. That is, the intention offered together with the gift, the material thing, is as important as the thing itself.

Therefore, to understand a group, it is essential to be attentive to what appears in the concrete scenes of daily life, as in the case of eating and sharing food, by analyzing the movements (giving, receiving, and reciprocating), intentions, and symbolism. In this sense and in light of the theory of the gift, Martins [20] suggests understanding gifts as "gifts of appearing", that is, analyzing, from the food that circulates in groups, how people appear, or in other words, how they present their identities and would like to be recognized. The gift of appearing is approached by Martins [20] as perception: what is given is part of the self-presentation. In making themselves appear in the sharing and consuming of food, human beings reveal themselves in their fullness, imprinting their identity in and on the world.

\section{METHODS}

This study emerges from a larger research project undertaken to investigate the implication of relationships and identities in caring for the chronically ill in rural areas [21]. Daily eating, even though it was not a primary objective, was, however, something that always appeared in the research, and proved itself unique to rural identity. It was impossible not to be touched by food as a "text" that spoke volumes about identity. In this sense, what needed to be accomplished was the reading of this text. Thus, what is presented here are the snippets on eating produced in the larger study [21].

In spite of the initial uncertainties of someone coming from the health field and performing ethnography for the first time, the experience was unique, because it made it possible to understand Godbout [19], when he comments that only someone who possesses the spirit of the gift can see it in action. This means that in order to use the theory of the gift as a theoretical-analytic reference, it was also necessary to enact it in the research, immersing oneself in the field and in the context, renouncing control of a defined path, and becoming available to participate in rural daily life and its various shared meals: this involved using food as a text that speaks of identity through the continual gifting-receiving-reciprocating of goods and ways.

The ethnography was conducted for nine months in a rural area of a municipality in the southern part of Rio Grande do Sul, known as the national capital of family agriculture. The municipality has 53,259 inhabitants, with the majority of the population living in rural areas (65.6\%) [22]. The choice of the municipality and locality were because of the accumulation of pertinent information and relationships produced by the research group's previous studies. These provided an adequate basis for the study theme.

We were able to maintain contact with participants from the larger survey [21] to identify a total of 21 interlocutors. We maintained close relationships with ten of the local residents and 
participated in their daily lives. They were selected because they were interlocutors in the group's previous research, as well as being diverse: six women and four men; ages ranging from 35 to 69 years, five of whom were retired farmers and five non-retired farmers. The other 11 were people, who, given their life histories and/or internal and/or external positions in the rural locality could contribute to understanding the local context: these included one former resident of the locality, six leaders who worked in the community, school, churches, or community association; four public servants who worked on public policies related to food (one from primary health care and three from social assistance).

In terms of research techniques, we used participant observation of the daily life of the ten rural inhabitants, whose data were recorded in a field diary shortly after observation, as well as at least one interview with all of the participants, conducted in their homes or at their place of work for people outside the locality. The interviews followed semi-structured scripts taken from the larger research project and were all recorded in audio and later transcribed.

To read the data produced we used interpretative analysis; the basis for categorizing the information was the interlocutional data and gift theory was used as a reference. For Geertz [23], the interpretive analysis begins in the field, emerging from a direct contact with the details of the daily life of an "other." For the author, this researcher-researched interaction - the meeting of scientific knowledge and common/everyday sense - can be understood as the science of interaction, and therefore, it is interpretive. When practicing an interpretive science, care should be taken not to invent an explanation or category, arbitrarily resorting to the imagination, nor classifying and labeling phenomena according to theory: instead, one should be interpretive in the search for understandings about the phenomenon studied.

QSR International NVivo 8.0 software (QSR International, Melbourne, Australia) was used to organize the data. This application provided tools for the storage and encoding of information, and for generating data reports. The research was approved by the Ethics and Research Committee of the Universidade Federal do Rio Grande do Sul (UFRS, Federal University of Rio Grande do Sul) (approval No.2008077) and all the participants signed an informed consent form.

It is important to highlight that a more holistic approach to the relationship between eating and identity was made possible by the sum of at least three elements: the openness of the ethnographic method allowed field data to emerge; the readings of other ethnographies [24] that were, in a certain way, a training for the field; and the intellectual effort to understand, from the theory of the gift and with reference to the socio-anthropology of diet, the signs which appeared in the form of food.

\section{RESULTS AND DISCUSSION}

Starting from the assumption that food can be understood as a gift, that is, a good loaded with meanings, some analytical categories that speak to the main characteristics of the community are grasped from the relationships that traverse food. These characteristics, which through the use of food and its symbolism, take the form of "gifts of appearing" speak of collective identity. From these the rural people have empirically manifested the marks of their identity and how they want to be recognized.

In this sense, the following sections present two major categories that emerged from the field and from the dialog with the theoretical reference: (i) a category that speaks of a strong stigma that people want to leave in the past. It arose in the form of very subtle revelations about local history. 
They were stories that the community raised at more intimate moments of sharing meals, such as Sunday lunches, in which the closest people share the meal in an intimate process of giving-receivingreciprocating; and (ii) a second category that speaks more of reactions to the stigma. This category takes the form of characteristics that people would like to be more visible to make them appear as important values that they defend in the constitution of their identity.

\section{Appearing in the intimacy of commensality: Stories and stigmas of the past}

The practice of ethnography, with its openness to following the direction traced by the participants, was fundamental to understanding how the gifts circulating in relationships implicitly identified the people. That is to say, that there were many moments, in which one was free, as a researcher, to participate in the daily life of the rural locality. It was precisely in the invitations to share meals with the interlocutors that matters on the guarded history of stigma were shared.

According to reports from the research participants and records from other authors [21], the form of the rural locality was possibly the result of the breakdown of the sesmarial system, with the land passing to a single family that, over time, divided it among heirs who, in turn, sold their shares. Currently, the locality is characterized by having the largest number of small family establishments in the municipality, with total areas consisting of seven to ten hectares. Family agriculture stands out: the main occupation of people is in agriculture with tobacco and fruit production for self consumption.

There are structures such as an elementary school, Catholic and evangelical Pentecostal churches, a community association headquarters, as well as a health center. The emergence of these institutions, as some people reported, was the result of internal initiatives by the residents themselves.

However, what was remarkable in the history of the locality is that, even though it is currently "a paradise of a place; it had a difficult past" (Rosa, 60 years old, retired), as one interlocutor put it. Precisely because of these aspects, explanatory elements emerge that evoke the people of this rural life.

When people from outside the rural area were approached, one of the first comments that frequently arose during dialog was a reference to how the place was referred to: "pulguedo" (which in the regional vocabulary of the Rio Grande refers pejoratively to a poor neighborhood or village). On the other hand, in conversations with the locals, references to the term "pulguedo" rarely appeared - being used by just a few people, and only after a strong relationship had been established.

It was precisely by accepting an invitation for a Sunday lunch and realizing that some of the barriers between the researcher and local people were being overcome, that the rural host, in light of the gift theory, offered along with the food and without being asked, the first internal comment to explain the difficult past. The interlocutor reveals that in the past, the locality "was very poor, it was called 'Rincão dos pulguedos', but not today, now it is the best place to live" (Pedro, 54 years old, farmer).

When examining the work of Goffman [25] and the implications of constructing a label like "pulguedo" it is possible to understand the term as a stigma, something that is established in social interactions based on a special type of relation between an attribute and a stereotype. In this sense, a stigma would be an accusation of imperfections, that is, of elements that imply an inferiority in the target. It constructs an image, or even an identity for the other that, in fact, relates to different attributes. 
It was also after sharing a lunch at the house of another interlocutor, João, a 49-year-old farmer, that he revealed stories of the past that helped in understanding the characteristics that were at stake in the past mode of living, in former times when the stigma that distinguished them from the "others" was constructed. At that time, João revealed, people had everything they needed at hand: the food existed because they planted crops and raised animals for the sustenance of the family; there was water to heat the mate, and wood for the fire. Another major concern, unlike today, was to build homes without masonry bricks. Savings were reserved for when there was some special need, such as a health problem or the funeral of a family member.

In the interlocutor's explanation, this behavior justified people's lives in the past. Even with differences in the social and economic conjunctures to which they were subjected, the community was stigmatized ethnically and segregated because of their origin and their different ways of living compared to others, especially the descendants of Germans who were very common in the neighboring communities of southern Brazil. In other words, the community had roots in the gaúcho, who were characterized as a social group marginalized by the landowners of the past because of their origin in the ethnic conjunctions of the Portuguese with the Indians, and the Spanish and Negroes [26]. The gaucho had a characteristic way of living and working based on animal care, and were subordinate to the rancher. In this way, the locality was considered inferior in relation to those areas predominantly colonized by descendants of Germans. Those areas were more ethnically closed, and were comprised of autonomous farmers with a different way of life [26].

It should also be noted that when they say that today the place is a paradise, they display other aspects of their identity. These traits denote a desire for a change of image, and overcoming a difficult past that detracted from them; they also signify new signs or symbols of prestige [25], as discussed in the following section.

\section{(Re)appearing for food: Signs of a new identity}

The construction of identity is complex. For Bauman [27], identity is projected by individuals/ groups themselves or by others who do not share the same principles. Thus, we should defend the identities projected by the people themselves, and fight for these rather than the identities imposed by others.

In contrast to the stigma that undermined them, it was by way of food, as a "gift of appearing" [20] that we were able to grasp some clues as to how people preferred to identify themselves, that is, how they wanted to (re)appear in the face of stigma.

\section{To appear capable of work is also to sustain the honor of the family: The abundance of Tuesday}

Research was usually carried out in people's homes during afternoon coffee - a time when the whole family would routinely gather to eat. The shared meal included freshly baked breads and cakes, jams, some kind of animal fat and coffee, always well served. There was also the insistence to always take a little more. The quantity of food and its capacity to strengthen the body were part of eating and that, in fact, was the way that the community showed how far they were moving away from the world of past difficulties.

The food served and shared seemed to signify honor in having the means to maintain the reproduction of the family and in working to produce or to gain sustenance. Affirmations such as 
"food never failed" (Diva, 69 years old, retired) were proudly expressed as the field journal record illustrates. In this record there is another demonstration of how food and work can be a symbol of the prestige (or lack thereof) that marked their identity:

As we say good-bye, she invites us to lunch on another day so we can eat peas with chicken. I say I would love to come. I also say in case it was, like today, a day too cold to slaughter the chicken or if there was no chicken, it would not bother us, as we would eat the same as we had had for lunch today. As if feeling offended, she reacts and says firmly: we a/ways have chicken, we are never without it, and cold is no excuse not to work. On the next day, on Tuesday, we were served a banquet (Ruiz, 2013, p.97) [21].

Likewise, in an interview with a servant of the municipality's Social Assistance Department, she reported that while in contact with rural residents, in trying to identify possible cases of food and nutritional insecurity, a person with knowledge of the group as a whole had told her that "no one [there] has a problem like that". That is, no one there would be likely to need assistance with basic food baskets. From this perspective, not being able to ensure the needs of the family would be met with their own work and therefore receiving outside or governmental assistance, would in itself degrade and dishonor the community [28].

Thereby, it can be seen that food speaks of the family and of the values shared by all of the community $[29,30]$. With the food and the labor that either directly produces it, or indirectly provides the income to acquire it, comes the sustenance of the family, the honor, and the prestige that no longer (re)classifies them as "pulguedos"; this is how they want to appear and have their identity recognized.

\section{To appear able to consume the same goods as urban people: Cartons of milk and bread from the bakery}

Another relevant characteristic of the identity that the community connected with food was the valuation of some goods, such as those that urban people also consume. It was observed that cartons of milk appeared to be thought healthier than milk direct from the cow; together with the homemade bread, bakery bread was served to the guests. This appeared better as the bread arrived in a bakery van and was the remedy of the pharmacy, unlike the herbal tea from the garden, which was always at hand for an ailment.

Making use of typical city goods does not signify a desire to be there. On the contrary, the countryside is the "best place" according to the reports of the interlocutors. However, to invest in these goods could be related to not wanting to be different from others.

References [29] on the behavior of rural young people who seek an autonomous income point out that the objective of seeking this income would not be autonomy from the rural areas or the family, but the ability to access goods available to young city dwellers. For young people, this represented their insertion into the urban world without leaving their rural setting.

There is a symbolic dimension to this consumption. Consumption would not be seen as something individual, but something that has a social meaning, because it speaks of what is shared by people: their experiences. Thus, to "possess" goods, in addition to meeting material needs, presents meanings that establish and maintain social relations $[11,29]$. That is, the "possessing" also seemed to be important to informing and mediating relations from a perspective of equality. 
Food, according to Mintz [31], is capable of entering into every being, and our bodies can be considered the result - the product; our character can, in turn, be revealed by the way we eat. Thus, we are what we eat, both materially (through the nutrients that make up our body), and symbolically (through our imagery). This is Fischler's "incorporation principle" [32]: in eating, in meals, and in what is or is not consumed, we practice the values, risks, and innovations of living; we construct identities; and, by expressing or affirming these we register them as belongings, as group distinctions, or even as signs of equality and prestige in relation to "others". This was observed in the contact with the study locale.

\section{To appear capable of honoring commitment with the other and with the place: Giving-receiving-reciprocating the potato}

It was found that the give-receive-reciprocate principle, besides communicating values, was also a value held by the interlocutors in the research. We observed a commitment to relational games. Even though freedom may occur, and it does occur, the moment a relationship is accepted, it is because one is willing to maintain it, with everything that that entails [19].

To better illustrate people's commitment to relational games, we cite an observed episode. It was already late afternoon when leaving Dona Alzira's house to meet another interlocutor. Her husband, Bartolomeu, appeared offering a motorcycle ride to another point in the locality. At the same time, he would take to the other interlocutor a seedling of a different kind of potato that he had obtained, which was said to be good for lowering cholesterol. Upon arriving at the destination, Bartolomeu soon delivered the seedling to the woman and told her how she should plant it. The recipient, taking the potato, asked: "How much do I owe you"? (Diva, 56 years old, retired). He replied: "Well, nothing, just plant it, care for it, and pass it on" (Bartolomeu, 52 years old, farmer).

When Bartolomeu left, the woman immediately went to the garden to plant the potato. After all, even if Bartolomeu had already left, she was now committed to taking care of the potato so she could share it with others; if she did not, she would be breaking her commitment.

This was a simple example, but very representative of the value that social relations have. Other examples like this often recurred. All discourses that speak of the gift and its norms, which at the moment of the relationship are implicit, are expected to be fulfilled. To break with them is to break with the commitment to the formation of local customs, and the collective identity [16]. Moreover, they are discourses that speak of a rural quality: reciprocity [30,33].

Finally, it was learned that food, and sharing it, is also a way of marking identities [34]. In eating and its related activities, the community made it clear how they wanted to be known: eating introduced characteristics of an identity that were different from those of the poor and those without social value; it was also an activity that made them visible and unique as a rural social group.

\section{CONCLUSION}

In this research, the rural community showed that using food as a gift has some elements that in relationships with us and with others, demonstrated that they had had a difficult past, fraught with stigma. At the same time, a reaction to this had arisen and a collective search was employed to consolidate some of the characteristics that could re-qualify the community as a group: that is, that could make them visible (reappear) through characteristics different from those that stigmatized 
them. The people made themselves understood through the honor of working and sustaining the family, and having the material potential to place themselves on an equal footing with those from the outside city, while also being able to fulfill their commitments to the group. It was with these elements that people sought to defend their identity to outsiders and to themselves.

Food has proved to be a privileged space for analyzing that identity and ways of living as a group. From the perspective of gift theory, food and rural life become more than just material activities deprived of relevance and personality. Within the material nature of eating and the rural areas there are subjects whose collective thoughts and identities signal, to a certain extent, their way of living and relating to each other.

Finally, in light of the discussion raised, the assumption is made that rural practices related to food may be different from those of others. There should be a capacity to respect and listen to people's needs and to promote a more dignified life, insofar as it is important to seek to understand diet beyond the biological and the individual. Indeed, it is also a complex and revealing sociocultural phenomenon that includes the modes of belonging to a group.

\section{CONTRIBUTORS}

ENF RUIZ conceived the research project, worked on data collection, interpretation of results, writing and reviewing the article. TE GERHARDT conceived the research project, worked on interpreting the results, writing and reviewing the article

\section{REFERENCES}

1. Canesqui AM. Antropologia e alimentação. Rev Saúde Pública. 1988;22(3):207-16.

2. Diez-Garcia RW. Mudanças alimentares: implicações práticas, teóricas e metodológicas. In: Diez-Garcia RW, Cervato-Mancuso AM. Mudanças alimentares e educação nutricional. Rio de Janeiro: Guanabara Koogan; 2011.

3. Almeida MG. Para além das crenças sobre alimentos, comidas e sabores da natureza. Mercator. 2017;16:1-13.

4. Matta R. Sobre o simbolismo da comida no Brasil. Corr Unesco. 1987;15(7):22-3.

5. Menezes SSM. Comida: identidade, tradição e cultura enraizada nas manifestações do catolicismo em Sergipe. Ateliê Geo. 2014;8(2):274-89.

6. Cavalcanti LG, Santos LAS, Santos LL, Magalhães LM, Santos MO. Comida e identidade: construções identitárias de comensais da feira das Sete Portas, Salvador, Bahia. Anais do I Seminário Alimentação e Cultura na Bahia; 2012 jun 13-15; Feira de Santana, Brasil. Feira de Santana: UEFS; 2012:1-8.

7. Rodrigues CE. A influência da alimentação em quem somos. Diálogos Saberes. 2016;12(1):9-24.

8. Collaco JH, Menasche R. Comer contemporâneo: e não é que comida continua boa para pensar? Soc Cult. 2015;18(1):5-11.

9. Maciel ME. Identidade cultural e alimentação. In: Canesqui AM, Diez-Garcia RW, organizadores. Antropologia e nutrição: um diálogo possível. Rio de Janeiro: Fiocruz; 2005.

10. Rocha CPV. Comida, identidade e comunicação: a comida como eixo estruturador de identidades e meio de comunicação. Bibl Online Ciênc Comun. 2010:1-7.

11. Nascimento AL, Menasche R. Comida, ato alimentar e outras reflexões consumidas. Contexto Alim. 2017;5(2):3-13.

12. Castro HC, Maciel ME, Maciel RA. Comida, cultura e identidade: conexões a partir do campo da gastronomia. Ágora. 2016;18(1):18-27. 
13. Paiva JB, Freitas MCS, Santos LAS. Significados da alimentação escolar segundo alunos atendidos pelo Programa Nacional de Alimentação Escolar. Ciênc Saúde Coletiva. 2016;21(8):2507-16.

14. Costa MC, Lopes MJM, Soares JSF. Agendas públicas de saúde no enfrentamento da violência contra mulheres rurais: análise do nível local no Rio Grande do Sul, Brasil. Ciênc Saúde Coletiva. 2015;20(5):1379-87.

15. Ruiz ENF, Santos VF, Gerhardt TE. Mediações na atenção à saúde sob a ótica da Teoria da Dádiva: a saúde da população rural em destaque. Physis. 2016;26(3):829-52.

16. Mauss M. Ensaio sobre a dádiva: forma e razão da troca nas sociedades arcaicas. In: Mauss M. Sociologia e antropologia. São Paulo: Cosac \& Naify; 2003.

17. Martins PH. A sociologia de Marcel Mauss: dádiva, simbolismo e associação. Rev Crit Ciênc Soc. 2005;73:45-66.

18. Caille A. Nem holismo nem individualismo metodológicos: Marcel Mauss e o paradigma da dádiva. Rev Bras Ciênc Soc. 1998;13(38):5-38

19. Godbout JT. O espírito da dádiva. Lisboa: Instituto Piaget; 1997.

20. Martins PH. O dom como percepção [audiovisual]. Recife: Peixe Boi Filmes; 2011 [citado 20 mar 2018 ]. Disponível em: https://www.dailymotion.com/video/xje7rf

21. Ruiz ENF. Relações sociais nas situações de adoecimento crônico no rural: expressões de cuidado e de sofrimento na perspectiva da dádiva [Tese]. Porto Alegre: Universidade Federal do Rio Grande do Sul; 2013.

22. Instituto Brasileiro de Geografia e Estatística. Censo demográfico 2000: características da população e dos domicílios: resultado do universo. Rio de Janeiro; 2000 [citado 2011 maio 5]. Disponível em: http://www. ibge.gov.br/home/estatistica/populacao/censo2000/

23. Geertz C. Nova luz sobre a antropologia. Rio de Janeiro: Jorge Zahar; 2001.

24. Ramos MO. A "comida da roça" ontem e hoje: um estudo etnográfico dos saberes e práticas alimentares de agricultores de Maquiné (RS) [Dissertação]. Porto Alegre: Universidade Federal do Rio Grande do Sul; 2007.

25. Goffman E. Estigma: notas sobre a manipulação da identidade deteriorada. Rio de Janeiro: LTC, 2008.

26. Fialho MA. Rincões de pobreza e desenvolvimento: interpretações sobre comportamento coletivo [Tese]. Rio de Janeiro: Universidade Federal do Rio de Janeiro; 2005.

27. Bauman Z. Identidade. Rio de janeiro: Jorge Zahar; 2005.

28. Ruiz ENF, Gerhardt TE. Políticas públicas no meio rural: visibilidade e participação social como perspectivas de cidadania solidária e saúde. Physis. 2012;22(3):1191-209.

29. Wedig J, Martins VS, Menasche R. Plantar, criar, comer: classificações da comida e das pessoas no interior de famílias rurais. Anais do $8^{\circ}$ Fazendo Gênero: corpo, violência e poder; 2008, ago 25-28, Florianópolis, Brasil. Florianópolis: UFSC; 2008:1-7.

30. Menasche R, Marques FC, Zanetti C. Autoconsumo e segurança alimentar: a agricultura familiar a partir dos saberes e práticas da alimentação. Rev Nutr. 2008;21Suppl:145s-58s. http://dx.doi.org/10.1590/S1415-52 732008000700013

31. Mintz SW. Comida e antropologia: uma breve revisão. Rev Bras Ciênc Soc. 2001;16(47):31-42.

32. Fischler C. El (h)omnívoro: el gusto, la cocina y el cuerpo. Barcelona: Anagrama; 1995.

33. Woortmann K. Com parentes não se negucia: o campesinato como ordem moral. Anu Antropol. 1990;87:11-73.

34. Lima RS, Ferreira Neto JA, Farias RCP. Alimentação, comida e cultura: o exercício da comensalidade. Demetra. 2015;10(3):507-22. http://dx.doi.org/10.12957/demetra.2015.16072 